\title{
TUTURAN TABU DALAM FILM JEPANG TENTANG REMAJA
}

\author{
Husnul Hamidiyah \\ Sekolah Menengah Atas Negeri 1 Waru Sidoarjo
}

\begin{abstract}
Abstrak: Penelitian ini bertujuan untuk mengkaji informasi mengenai tuturan yang dianggap tidak sopan dan dapat membedakan bentuk, motif, fungsi, konteks emotif, dan strategi xfemisme pada penggunaan tuturan tabu dalam situasi percakapan bahasa Jepang. Penelitian ini berlandaskan pada teori para ahli linguistik yaitu Allan dan Burridge (2006), Ullmann (2006), Searle (1975), Boeree (2006), Hughes (1991), Yonekawa (2008), dan Fargo (2009). Penelitian ini menggunakan metode telaah pustaka dan metode analisis deskriptif kualitatif. Sumber data adalah film Jepang bertema tentang remaja yaitu Confessions (2010) karya Tetsuya Nakashima, Detroit Metal City (2008) karya Toshio Lee, dan sekuel Crows Zero (2007 dan 2009) karya Takashi Miike.Data penelitian ini berupa kalimat yang mengandung tuturan tabu yang ditemukan sebanyak 70 data. Hasil pengklasifikasian dan analisis data menunjukkan bahwa (1) bentuk tuturan tabu dengan sistem ekskresi yaitu 1 data, organ tubuh yaitu 3 data, aktivitas seksual yaitu 5 data, kelainan seksual yaitu 2 data, kematian yaitu 2 data, pembunuhan yaitu 7 data, penamaan/ pengalamatan yaitu 13 data, tempat/ objek sakral/ religi yaitu 7 data, penyakit yaitu 2 data, hewan yaitu 6 data, fisik tidak ideal yaitu 1 data, mental di bawah normal yaitu 14 data, dan kotoran yaitu 7 data; (2) motif tuturan tabu dengan motif taboo of fear, yaitu 7 data, motif taboo of delicacy yaitu 11 data, dan motif taboo of propriety yaitu 52 data; (3) fungsi tuturan tabu dengan fungsi asertif yaitu 16 data, fungsi direktif yaitu 7 data, fungsi komisif yaitu 1 data, fungsi ekspresif yaitu 46 data, dan fungsi deklaratif nol data; (4) konteks emotif tuturan tabu dengan konteks keterkejutan yaitu 3 data, konteks ketakutan yaitu 4 data, konteks kemarahan yaitu 39 data, konteks kesedihan yaitu 7 data, konteks keinginan yaitu 7 data, konteks kebahagiaan yaitu 7 data, dan konteks kebosanan yaitu 3 data; (5) strategi $\mathrm{x}$-femisme tuturan tabu dengan tipe disfemisme yaitu 27 data, ortofemisme yaitu 40 data, dan eufemisme yaitu 3 data. Hasil analisis dapat disimpulkan secara umum bahwa penggunaan tuturan tabu senantiasa didasari dengan latar belakang kebahasaan seperti bentuk, motif, fungsi, konteks emotif, dan strategi x-femisme. Kemudian, penggunaan tuturan tabu juga mempengaruhi keberhasilan komunikasi yang diharapkan antara penutur dan petutur.
\end{abstract}

Kata kunci: Bentuk, Motif, Fungsi, Konteks Emotif, Strategi X-Femisme

\begin{abstract}
The research is to find out the information of the speeches which are considered impolite and to differentiate the form, motif, function, emotive context, and x-femisme strategy of taboo speeches in Japanese stituational conversations. The research is based on the arguments of linguists such as Allan and Burridge (2006), Ullmann (2006), Searle (1975), Boeree (2006), Hughes (1991), Yonekawa (2008), and Fargo (2009). The research uses library research and qualitative descriptive methods. The sources of data are youth themed Japanese movies Confessions (2010) by Tetsuya Nakashima, Detroit Metal City (2008) by Toshio Lee, and sequels of Crows Zero (2007 \& 2009) by Takashi Miike. The research data are in the forms of sentences which comprise 70 taboo speeches. The results of classification and analysis show that (1) the form(s) of taboo speeches which point to excression system is 1
\end{abstract}


evidence; body parts are 3 evidences; sexual activities are 5 evidences; sexual deviations are 2; deaths are 2; murders are 7; apellations are 13; places/sacred objects/religious are 7; diseases are 2; animals are 6; non-ideal phisical appearance is 1; mental disorders are 14; and trashes are 7; (2) the motifs of taboo speeches are classified as: taboo of fear denotes 7 evidences, taboo of delicacy denotes 11 evidences, and taboo of propriety denotes 52 evidences; (3) taboo speeches function with assertive functions are 16 evidences, directive functions are 7, commisive function is only 1, expressive functions are 46 evidences, and no declarrative function; (4) emotive contexts of taboo speeches which encompass surprise contexts are 3 evidences, fear contexts are 4 evidences, anger contexts are 39 evidences, sad contexts are 7, want contexts are 7, happy context: 7, and boring contexts are 3 evidences; (5) taboo speeches of $x$-femisme strategy of disfemism denotes 27 evidences, ortofemism: 40 evidences, and eufemism: 3 evidences. Generally speaking, the use of taboo speeches are always attached to language system such as form, emotive context, and x-femism strategy. Thus, the use of the taboo speeches also influence the success of communication between communicators.

Keywords: form, motif, function, emotive context, $x$-femism strategy

\section{Pendahuluan}

Suatu tuturan dianggap baik atau tidak baik bergantung pada persepsi masyarakat bahasa itu sendiri. Bahasa memiliki konvensi hakiki. Ada kalanya tuturan yang menurut suatu masyarakat dianggap baik, namun menurut masyarakat lainnya dianggap tidak baik. Itu merupakan cerminan bahwa bahasa bersifat arbitrer dan relatif. Meskipun suatu tuturan dianggap tabu, bukan berarti tuturan tersebut tidak boleh dituturkan. Jika suatu tuturan dari suatu bahasa dirasa tabu untuk diucapkan, maka penutur memiliki beberapa strategi komunikasi. Penutur boleh tetap mengucapkan tuturan tabu tersebut seperti yang terjadi di dunia medis saat mengucapkan beberapa nama penyakit atau organ tubuh yang dianggap tabu. Selanjutnya penutur boleh memperhalus cara pengucapan tuturan tabu tersebut seperti ketika seseorang akan mengutarakan tuturan tabu tetapi tetap ingin dianggap santun. Selain itu, penutur boleh memperkasar tuturan tabu tersebut ketika dia merasa ingin meluapkan rasa emosionalnya. Tuturan yang diucapkan oleh penutur tersebut mencerminkan bagaimana pikiranpenuturnya.

Tuturan tabu seharusnya tidak etis untuk diutarakan karena dianggap vulgar dan seakan dapat mencoreng wajah orang lain yang dikenai tuturan. Namun kondisi yang terjadi dalam masyarakat adalah tuturan tabu tersebut malah seringkali diucapkan penutur dengan motif menyinggung perasaan petutur. Tuturan tabu yang pada dasarnya sudah memiliki makna yang sejatinya tabu atau vulgar untuk diutarakan, seringkali malah menjadi pemicu penutur untuk mengutarakan dengan lantang dan diperkasar agar lebih mengena dan melukai perasaan petutur. Tuturan yang diperkasar inilah yang disebut dengan istilah disfemisme. Disfemisme ini termasuk dalam kategori tidak sopan dan tidak menghargai wajah petutur.

Tuturan tabu yang standar disebut ortofemisme. Ortofemisme ialah tuturan yang lurus, normal, tidak diperhalus ataupun diperkasar. Ortofemisme merupakan ekspresi normal dan tidak dibuat-buat. Pengungkapan tuturan tabu dalam bentuk ortofemisme biasa digunakan 
di dunia medis untuk mengungkapkan istilah ilmiah.

Masyarakat memberlakukan sanksi sosial pada orang yang mengucapkan tuturan tabu. Stereotip yang dikenakan pada masyarakat adalah karena kata-kata tabu dinilai tidak pantas. Maka dari itu ketika seseorang berniat mengucapkan suatu tuturan tabu, ia lebih dahulu harus menyaring dan menggantinya dengan tuturan yang lebih halus atau sopan. Tuturan yang diperhalus dalam linguistik disebut dengan istilah eufemisme. Eufemismesering digunakan sebagai pengganti tuturan yang kurang menyenangkan, dan ekspresi yang bisa menyinggung perasaan petutur. Ketika seorang penutur menggunakan eufemisme maka dapat dikatakan ia sedang menggunakan strategi kesopanan dalam berbahasa.

Munculnya tuturan tabu dalam bahasa Jepang semakin pesat. Disamping bahasa Jepang sendiri sudah kaya akan tuturan tabu, bahasa asing di luar Jepang juga memperkaya kuantitas tuturan tabu bahasa Jepang sehingga semakin bertambah. Pertambahan ini dapat dilihat dari jumlah kata yang terdapat dalam kamus bahasa Jepang yang mencapai ribuan entri kata, apalagi ditambah dengan kebiasaan masyarakat bahasa Jepang yang selalu mengadopsi kata-kata dari bahasa asing, utamanya dari bahasa Inggris. Jepang mengadopsi kata asing dan diserap dengan menamakannya sebagai gairaigo.Gairaigo adalah bahasa Jepang yang diadopsi dan diadaptasi dari bahasa asing di luar bahasa Jepang yang dituliskan dalam huruf katakana.

Bahasa dapat diekspresikan baik dalam bentuk tulisan atau lisan. Tuturan tabu yang dituliskan memiliki nilai rasa sederhana dibandingkan tuturan tabu yang diungkapkan dalam bentuk lisan. Tuturan tabu dalam bentuk lisan mengarahkan penutur untuk mengambil sikap harus dengan cara bagaimana mengatakan tuturan tabunya. Sementara itu petutur bertugas mencerna dan menginterpretasikan pilihan sikap dan diksi tuturan tabu yang disampaikan oleh penutur. Untuk mengetahui tuturan tabu secara lisan dapat dicermati dari media audio visual seperti film. Film dapat menampakkan suatu tuturan secara nyata dengan adanya ekspresi masing-masing tokoh serta bahasa tubuh yang dapat diamati secara langsung.

Dewasa ini media komunikasi bahasa semakin bervariatif seperti halnya media audio visual yang menyajikan film dengan didasarkan pada realita sosial. Realita sosial dapat berupa fenomena bahasa yang erat kaitannya dengan identitas bangsa. Demikian halnya, ketika seorang tokoh dalam suatu film yang mengucapkan tuturan tabu, hal itu merupakan suatu lambang yang menunjukkan dari negara mana seseorang itu berasal. Film merupakan suatu media ekspresi bahasa yang menjelaskan secara tersurat dan tersirat mengenai sisi emosional penutur. Sisi emosional yang memuat tuturan tabu ini umumnya terdapat dalam film seputar kehidupan remaja. Sebagaimana terangkum dalam penelitian tesis Hamidiyah (2013). Dalam penelitian tersebut ada tiga genre film yang diteliti yakni genre drama, komedi, dan laga. Pada genre drama terpilih sebagai sumber data adalah film Confessions (2010) yang pada pembahasan selanjutnya disingkat dengan Con. Pada genre komedi terpilih film Detroit Metal City (2008) yang disingkat dengan istilah DMC. Pada genre laga terpilih sekuel film Crows Zero (2007 dan 2009) yang disingkat sebagai CZ1-2.

Tuturan tabu dalam penggunaan sehari-hari diwujudkan dalam bentuk ekspresi dan gerakan yang secara sosial dikonstruksi sebagai ketidaksopanan atau kevulgaran. Namun sejauh mana suatu tuturan tabu dianggap menyakitkan atau menyenangkan tergantung pada konteks 
yang melatarbelakangi penutur dan petutur. Tuturan (1) berikut merupakan contoh aplikatif tuturan tabu. Negishi bertemu dengan bintang pop idolanya, lalu Negishi diminta untuk unjuk gigi menyanyikan lagu karyanya sendiri. Belum tuntas bernyanyi, lagu Negishi diputus, Negishi dihina oleh bintang pop idolanya tersebut di hadapan wanita yang disukainya, Aikawa. Sehingga Negishi kabur serta marah, lalu mengucapkan suatu tuturan tabu yang terkait dengan hewan ternak.

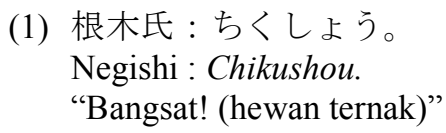

(DMC 45:13)

Tuturan (1) di atas termasuk dalam tuturan tabu terkait hewan yang berfungsi untuk mengekspresikan kesedihan yang dialami penutur. Tuturan ini timbul karena adanya pengalaman yang menyakitkan. Penutur tidak mengumpati petutur secara langsung karena petutur dan penutur saat kejadian pertuturan tabu tersebut tidak berada di satu tempat yang sama, melainkan petutur hanya sebagai referen tujuannya untuk mengumpat. Penutur yang berkepribadian kalem tidak memiliki keberanian untuk mengumpati petutur secara langsung, karena itu penutur mengumpat tanpa kehadiran satu orang pun. Dengan mengumpat, penutur ingin melepaskan emosi kesedihannya setelah dihina oleh penutur di depan umum.

Tuturan (2) ini adalah contoh aplikatif tuturan tabu yang termasuk ketegori menyenangkan. Genji memohon dengan melakukan ojigipada temannya yang bernama Ken agar diajarkan cara untuk dapat menjadi penguasa geng di SMA Suzuran. Ojigi merupakan budaya Jepang dengan membungkukkan badan kepada orang lain sebagai ekspresi salam, permintaan maaf, dan permintaan. Kedalaman bungkukan bergantung pada seberapa besar penghargaan pada orang lain (International Internship Programs, 2001:73). Ken tidak tega dan akhirnya memberitahukan triknya kepada Genji.
(2) ケン：男に2 本言うなね、じや、そうすぐ よ。手前のクラスを者にする方法教 えたれ。

Ken : Otoko ni nipon iuna ne, ja, sousuguyo. Temee no kurasu o mono ni suru houhou oshietare.

Ken : "Jangan bicara dua kali pada pria, ya, kita lanjutkan. Aku akan mengajarkan bagaimana cara menguasai kelas Kau berengsek.”

(CZ 1 26: 59)

Tuturan (2) tersebut mengacu pada tindakan menyenangkan didasarkan pada konteks yang melatarbelakangi tuturan tersebut, Genji dan「ケン」Ken saling berteman, walaupun $「$ ケ 」Ken mengucapkan kata「手前」temee yang secara gramatikal menurut Yonekawa berarti fucker, dipshit, dan asshole (2008:27) dan dalam bahasa Indonesia bermakna berengsek. Namun gerakan tubuh yang menunjukkan rasa berminat, mimik wajah yang senang, dan ekspresi ketertarikan yang ditunjukkan oleh penutur mengindikasikan suatu hal yang menyenangkan dan akrab. Penggunaan「人 称代名詞」ninshoudaimeishi (pronomina persona) tuturan tabu「手前」 temeemengekspresikan solidaritas dengan orang lain.

Kedua uraian contoh tuturan di atas memberikan suatu bentuk gambaran mengenai adanya bentuk dan fungsi pragmatis suatu tuturan yang memiliki sifat tabu. Hal ini mendorong peneliti untuk mengaji fenomena strategi $\mathrm{x}$-femisme apa yang digunakan pada tuturan tabu ditinjau dari fungsi pragmatis. Ada beberapa alasan yang mendasari peneliti memilih tiga film tentang remaja dari tiga genre film yang berbeda sebagai sumber data, yaitu Con, DMC, CZ 1, dan CZ 2. Pertama, meskipun berasal dari genre yang berbeda (yaitu 
drama, komedi, dan laga) namun ketiga film ini memiliki kesamaan yakni berlatar lingkungan remaja yang keras, karena itu dalam percakapan antar tokohnya banyak memuat tuturan-tuturan tabu. Kedua, untuk menunjuk pada satu makna yang sama, ketiga film ini memiliki variasi $\mathrm{x}$-femisme yang beragam, dari disfemisme, ortofemisme, hingga eufemisme. Ketiga, karena ketiga film ini merupakan suatu film, maka memudahkan peneliti untuk mengamati ekspresi para tokoh saat mengutarakan tuturan tabu dan fitur paralinguistik yang tersirat pada setiap monolog atau dialognya. Hal ini memudahkan peneliti untuk mengidentifikasi konteks suatu tuturan tabu dan tingkat ketabuan suatu tuturan.

Berdasarkan latar belakang tersebut penelitian ini berupaya untuk memerikan bentuk, motif, fungsi, konteks emotif, dan strategi $\mathrm{x}$-femisme pada penggunaan tuturan tabu dalam film Con, DMC, CZ 1, dan CZ 2. Pijakan data tuturan tabu seluruhnya diperoleh dari ketiga film tersebut yang dirangkum dalam suatu korpus data makna tuturan tabu. Bentuk tuturan tabu ini meliputi kata, frasa, klausa, dan kalimat. Akan tetapi ketika dipasangkan dalam korpus data, maka tuturan tabu hanya mengelola data berupa kata saja. Tindakan ini bertujuan untuk memilah dan memilih strategi $\mathrm{x}$-femisme mana yang digunakan oleh penutur serta bagaimana kedudukan maknanya setelah diperingkatkan.

Film merupakan media komunikasi yang mampu menghegemoni budaya; seperti masuknya budaya mengucapkan tuturan tabu dengan lantang melalui layar lebar yang menjadikannya membudaya. Hal tersebut yaitu salah satu alasan diadakannya penelitian mengenai penggunaan tuturan tabu dalam film Jepang tentang remajadengan harapan agar pembelajar bahasa bisa mendapatkan informasi mengenai bentuk, motif, fungsi, konteks emotif, dan strategi $\mathrm{x}$-femisme tuturan tabu atau tuturan yang dianggap kurang sopan serta dapat membedakan situasi percakapan bahasa Jepang.

\section{Metode Penelitian}

Metode penelitian yang digunakan adalah metode deskriptif kualitatif sebab metode ini bersifat memerikan jawaban atas rumusan masalah secara terperinci. Djajasudarma (1993:8) mengemukakan bahwa penelitian deskriptif kualitatif adalah metode yang bertujuan membuat deskripsi sistematis, faktual, dan akurat mengenai data, sifat serta hubungan fenomenafenomena yang diteliti.

Metode deskriptif kualitatif digunakan untuk menguraikan dan menganalisis data tuturan tabu dalam film Con, DMC, CZ 1, dan $\mathrm{CZ}$ 2. Metode ini digunakan untuk menganalisis beragam bentuk dan konteks yang melatarbelakangi tuturan tabu ditinjau dari segi pragmatis berdasarkan teori yang dikemukakan dalam bab dua. Pada dasarnya teori yang paling mendasari dan mengilhami peneliti dalam berpikir secara sistematis adalah teori yang dikemukakan oleh Allan dan Burridge (2006), Freud (1918), Ullmann (2006), Leech (1993), Jakobson (1998), Yule (1997), Boeree (2006), Yonekawa (2008), dan Fargo (2009).

Teori yang diutarakan oleh Allan dan Burridge (2006) untuk menjawab rumusan masalah pertama mengenai bentuk tuturan tabu. Lalu teori yang diutarakan oleh Ullmann (2006) untuk menjawab rumusan masalah kedua mengenai motif tuturan tabu. Lalu teori yang diutarakan oleh Jakobson (1998) dan Searle (1975) untuk menjawab rumusan masalah ketiga mengenai fungsi tuturan tabu. Lalu teori yang diutarakan oleh Boeree (2006) untuk menjawab rumusan masalah keempat mengenai konteks emotif tuturan tabu. Lalu teori yang diutarakan oleh Allan dan Burridge (2006), Hughes (1991), Ullmann (2006), Searle 
(1975), Boeree (2006), Yonekawa (2008), dan Fargo (2009) untuk menjawab rumusan masalah kelima mengenai strategi $\mathrm{x}$ femisme pada penggunaan tuturan tabu.

Metode deskriptif digunakan untuk menjabarkan dan menggambarkan secara sistematis rumusan masalah dalam penelitian ini. Metode deskriptif digunakan dalam penguraian data secara ilmiah sesuai dengan tujuan penelitian yang ingin dicapai. Penelitian ini menggunakan pendekatan kualitatif. Metode kualitatif adalah metode yang datanya berupa kata-kata dan bukan angka (Moleong, 1991:3) Karena itu metode analisis deskriptif kualitatif digunakan dalam penelitian ini untuk memberikan gambaran dan menguraikan makna yang mendalam mengenai permasalahan linguistik, khususnya dalam ranah kajian pragmatik. Analisis deskriptif kualitatif dimaksudkan untuk mendapatkan deskripsi mengenai bentuk, motif, fungsi, konteks emotif, dan strategi $\mathrm{x}$-femisme pada penggunaan tuturan tabu serta hubungan dengan konteks wacananya.

Penelitian ini juga menggunakan teknik telaah pustaka karena pemecahan masalah mengenai strategi $\mathrm{x}$-femisme pada tuturan tabu dilakukan berdasarkan tinjauan bahanbahan pustaka yang relevan. Bahan pustaka yang digunakan dalam penelitian ini adalah artikel hasil penelitian dalam jurnal ilmiah, buku, video, film, artikel, dan wacana yang memuat mengenai bentuk, motif, fungsi, konteks emotif, dan strategi $\mathrm{x}$-femisme pada penggunaan tuturan tabu serta hubungan dengan konteks wacananya.

Data penelitian ini berupa kalimat yang mengandung tuturan tabu. Adapun jumlah data akan ditentukan setelah data dipilah, dipilih, dikumpulkan, kemudian diklasifikasikan Hanya data yang representatif saja yang akan digunakan dan dianalisis. Data yang memiliki kesamaan tetap dihitung dan dianalisis dalam frekuensi dan persentase kemunculan data namun tidak akan dideskripsikan secara konkret. Setelah diteliti ditemukan 70 data dari ketiga genre film tersebut yang akan dijadikan sebagai objek analisis.

Fraser menyatakan bahwa dialog dalam drama maupun film benar-benar mirip dengan dialog alami atau dalam bahasa Jepang disebut「疑似自然談話」

giji shizen danwa dan dapat dijadikan sebagai objek penelitian (dalam Hashiuchi, 1999:38). Sumber data yang digunakan dalam penelitian ini adalah film Jepang yang memuat tuturan tabu yang diucapkan oleh tokoh-tokoh. Film yang dipilih dalam penelitian ini adalah Con, DMC, CZ1, dan $\mathrm{CZ}$ 2. Keempat film ini dipilih karena representatif untuk menggambarkan tuturan tabu dengan bentuk variatif. Karena meskipun banyak film Jepang yang di dalamnya memuat unsur tuturan tabu, namun ragam yang digunakan terkesan monoton.

Peneliti menggunakan dua macam teknik penelitian yaitu teknik simak bebas libat cakap dan teknik catat. Teknik simak bebas libat cakap dilakukan dengan cara mengamati dan menyimak dengan cermat mengenai penggunaan tuturan tabu dalam film Jepang tentang remaja Con, $\mathrm{DMC}, \mathrm{CZ}$ 1, dan CZ 2. Teknik catat dilakukan dengan cara mencatat monolog maupun dialog yang mengandung data tuturan tabu. Data diberi kode agar memudahkan pencarian. Format pemberian kode yakni penulisan huruf awal film, spasi, seri (bila ada), spasi, jam, titik dua, menit, titik dua, detik kemunculan tuturan tabu dalam tanda kurung. Sebagai contoh, kode (CZ 1 01:49:23) berarti bahwa data yang mengandung tuturan tabu tersebut muncul dalam film Crows Zero seri 1 jam ke-1, menit ke-49, detik ke-23. Data ditulis berdasarkan durasi waktu percakapan. Kemudian apabila dalam analisis ditemukan dua atau lebih percakapan yang dituturkan oleh tokoh yang sama dalam suatu peristiwa tutur, maka diberikan penomoran secara alfabetis. 
Teknik analisis dilakukan dengan cara mereduksi data, menyajikan data sementara, menverifikasi data, menguji kredibilitas data, dan melaporkan hasil penelitian. Sugiyono menyatakan penyajian data dalam penelitian kualitatif bisa dilakukan dalam bentuk uraian singkat, bagan, hubungan antar kategori, flowchart, dan sejenisnya agar data semakin terorganisasi dan tersusun dengan baik sehingga memudahkan pemahaman (2008:95). Miles dan Huberman menyarankan, dalam melakukan penyajian data, selain dengan teks naratif juga dapat berupa grafik, matrik, network, dan chart (dalam Sugiyono, 2008:95). Penelitian ini pun menggunakan chart dan grafik yang disajikan dalam bentuk frekuensi dan persentase kemunculan data tuturan tabu dalam film Con, DMC, CZ 1, dan CZ 2 untuk memudahkan pemahaman tentang penggunaan tuturan tabu dalam film dan dapat memudahkan pembaca untuk menarik kesimpulan secara cepat hanya dengan melihat grafik frekuensi dan persentase tersebut. Penggunaan angka pada persentase itu masih dalam tataran penelitian kualitatif. Karena sebagaimana diungkapkan Sugiyono di atas, penggunaan chart dan grafik tersebut menjadikan data semakin terorganisasi dan tersusun dengan baik sehingga memudahkan pemahaman pembaca.

Teknik pengujian keabsahan data dalam penelitian ini dilakukan dengan empat cara. Pertama yakni dengan meningkatkan ketekunan dengan melakukan pengamatan secara lebih cermat dan berkesinambungan. Kedua, triangulasi, yakni pengecekan data dari berbagai sumber dengan berbagai cara, dan berbagai waktu. Dalam hal ini peneliti menggunakan triangulasi data untuk menguji kredibilitas temuan dengan cara mengecek apa yang telah diperoleh dari berbagai narasumber yang merupakan pembicara asli bahasa Jepang. Ketiga, analisis kasus negatif, yakni kasus yang tidak sesuai atau berbeda dengan hasil penelitian hingga pada saat tertentu, peneliti mencari tahu secara mendalam mengapa masih ada data yang berbeda. Dengan demikian penelitian akan menjadi lebih kredibel. Keempat, menggunakan bahan referensi, yakni adanya pendukung untuk membuktikan data yang telah ditemukan oleh peneliti. Dalam penelitian ini peneliti menyertakan dokumen autentik berupa potongan video dalam format softfile yang diteliti (film Jepang Con, DMC, CZ 1, dan CZ 2), sinopsis film, artikel atau jurnal ilmiah resmi terkait tema penelitian, dan data yang telah divalidasi serta lembar validasi yang telah ditandatangani oleh triangulator yang seluruhnya berkaitan dengan data penelitian agar lebih dapat kredibel dan dapat dipercaya.

\section{Hasil Penelitian dan Pembahasan}

\section{Hasil Penelitian}

Berikut ini disajikan tabel hasil temuan data tentang bentuk, motif, fungsi, konteks emotif, dan strategi $\mathrm{x}$-femisme tuturan tabu yang diperoleh dari sumber data film Confessions (2010) karya Tetsuya Nakashima, Detroit Metal City (2008) karya Toshio Lee, dan sekuel Crows Zero (2007 dan 2009) karya Takashi Miike. 
Tabel 1

Bentuk Tuturan Tabu dalam Film Con, DMC, CZ 1, dan CZ 2

\begin{tabular}{|c|l|c|}
\hline No & \multicolumn{1}{|c|}{ Bentuk Tuturan Tabu } & $\begin{array}{c}\text { Jumlah } \\
\text { Data }\end{array}$ \\
\hline 1 & Sistem Ekskresi (excretory system) & 1 data \\
\hline 2 & Organ Tubuh (organs) & 3 data \\
\hline 3 & Aktivitas Seksual (sexual activities) & 5 data \\
\hline 4 & Kelainan Seksual (sexual disorders) & 2 data \\
\hline 5 & Kematian (death, die) & 2 data \\
\hline 6 & Pembunuhan (kill) & 7 data \\
\hline 7 & Penamaan/ Pengalamatan (naming, addressing) & 13 data \\
\hline 8 & Tempat/Objek Sakral/Religi (sacred things, God, religion) & 7 data \\
\hline 9 & Penyakit (disease) & 2 data \\
\hline 10 & Hewan (animal) & 6 data \\
\hline 11 & Fisik Tidak Ideal (not ideal physical) & 1 data \\
\hline 12 & Mental Di Bawah Normal(abnormal mental, stupid) & 14 data \\
\hline 13 & Kotoran (dirt) $\quad$ Jumlah Data & 7 data \\
\hline & & $\mathbf{7 0}$ data \\
\hline
\end{tabular}

Sementara itu motif tuturan tabu dikategorikan dalam tabel berikut.

Tabel 2

Motif Tuturan Tabu dalam Film Con, DMC, CZ 1, dan CZ 2

\begin{tabular}{|c|l|c|}
\hline No & Motif Tuturan Tabu & $\begin{array}{c}\text { Jumlah } \\
\text { Data }\end{array}$ \\
\hline 1 & Taboo of Fear (Adanya sesuatu yang menakutkan) & 7 data \\
\hline 2 & Taboo of Delicacy (Adanya perasan yang tidak enak) & 11 data \\
\hline 3 & Taboo of Propriety (Adanya sesuatu yang tidak santun) & 52 data \\
\hline \multicolumn{2}{|c|}{ Jumlah Data } & $\mathbf{7 0}$ data \\
\hline
\end{tabular}

Sementara itu fungsi tuturan tabu dikategorikan dalam tabel berikut.

Tabel 3

Fungsi Tuturan Tabu dalam Film Con, DMC, CZ 1, dan CZ 2

\begin{tabular}{|c|l|c|}
\hline No & Fungsi Tuturan Tabu & $\begin{array}{c}\text { Jumlah } \\
\text { Data }\end{array}$ \\
\hline 1 & Asertif & 16 data \\
\hline 2 & Direktif & 7 data \\
\hline 3 & Komisif & 1 data \\
\hline 4 & Ekspresif & 46 data \\
\hline 5 & Deklaratif & 0 data \\
\hline \multicolumn{2}{r}{} & Jumlah Data \\
\hline
\end{tabular}


Sementara itu konteks emotif tuturan tabu dikategorikan dalam tabel berikut.

Tabel 4

Konteks Emotif Tuturan Tabu dalam Film Con, DMC, CZ 1, dan CZ 2

\begin{tabular}{|c|l|c|}
\hline No & \multicolumn{1}{|c|}{ Konteks Emotif Tuturan Tabu } & $\begin{array}{c}\text { Jumlah } \\
\text { Data }\end{array}$ \\
\hline 1 & Konteks keterkejutan (surprise context) & 3 data \\
\hline 2 & Konteks ketakutan (fear context) & 4 data \\
\hline 3 & Konteks kemarahan (anger context) & 39 data \\
\hline 4 & Konteks kesedihan (sadness context) & 7 data \\
\hline 5 & Konteks keinginan (eagerness context) & 7 data \\
\hline 6 & Konteks kebahagiaan (happiness context) & 7 data \\
\hline 7 & Konteks kebosanan (boredom context) & $\mathbf{7 0}$ data \\
\hline & Jumlah Data & \\
\hline
\end{tabular}

Sementara itu strategi $\mathrm{x}$-femisme tuturan tabu dikategorikan dalam tabel berikut

Tabel 5

Strategi X-Femisme Tuturan Tabu dalam Film Con, DMC, CZ 1, dan CZ 2

\begin{tabular}{|c|l|c|}
\hline No & \multicolumn{1}{|c|}{ Strategi X-Femisme Tuturan Tabu } & Jumlah Data \\
\hline 1 & Disfemisme (Dysphemism) & 27 data \\
\hline 2 & Ortofemisme (Orthophemism) & 40 data \\
\hline 3 & Eufemisme (Euphemism) & 3 data \\
\hline \multicolumn{2}{r|}{ Jumlah Data } & $\mathbf{7 0}$ data \\
\hline
\end{tabular}

\section{Pembahasan}

Berikut ini adalah diagram frekuensi kemunculan tuturan tabudalam film Confessions (2010), Detroit Metal City (2008), dan sekuel Crows Zero (2007 dan 2009) yang terdiri dari jumlah keseluruhan 70 data. 


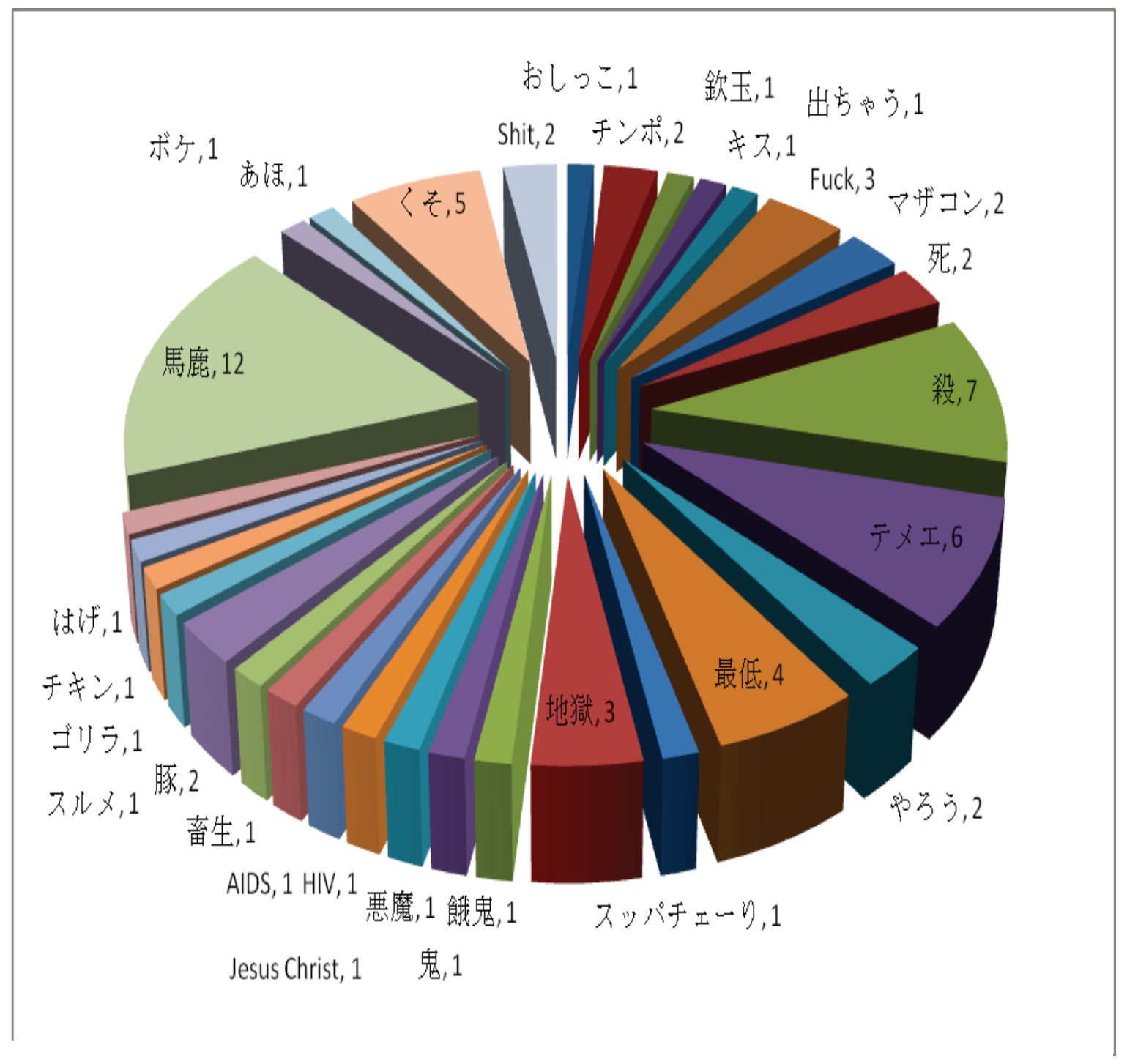

Diagram 1 Frekuensi Kemunculan Bentuk Tuturan Tabu

Tuturan tabuyang paling banyak muncul pada diagram di atas adalah 「馬 鹿」 baka yang berarti bodohdengan perolehan data sebesar 12 data. Hal ini disebabkan tuturan tabu yang terkandung dalam tuturan $「$ 馬鹿」 baka biasa digunakan di daerah Kansai seperti yang diungkapkan oleh Yonekawa (2008:32). Sejalan dengan hal tersebut film Detroit Metal City dan film sekuel Crows Zero 1 dan 2 ini sendiri pun berlatar di daerah tersebut sehingga tokoh-tokohnya pun sering menggunakan dialek Kansai dalam pertuturannya. Dalam dialek Kansai tuturan 「馬鹿」 baka dinilai sangat kasar dan sangat sering digunakan sebagai bahasa kolokial masyarakat setempat saat ingin mengumpat atau menghina orang lain. Native speaker, Emiko Watanabe, selaku triangulator data penelitian juga mengutarakan hal serupa.

Frekuensi kemunculan tuturan tabu yang terbanyak kedua adalah tuturan「殺 す」korosu dengan perolehan data sebesar 
7 data. Makna「殺す」korosu secara harfiah menurut makna kamus berarti bunuh. Ketiga film yang dijadikan sebagai sumber data penelitian ini berlatar kehidupan remaja yang keras dengan berbagai masalah polemik yang dialami para tokohnya, misalnya saja seputar pembunuhan, tawuran dan semacamnya. Karena itulah dalam data penelitian tuturan

「殺す」korosu cukup banyak ditemukan.

Tuturan「殺す」korosu sendiri dianggap tabu dan kasar karena makna dari tuturan tersebut adalah suatu tindakan untuk mengakhiri hidup seseorang.

Frekuensi kemunculan tuturan tabu yang terbanyak ketiga adalah tuturan 「テ メ $」$ temee dengan perolehan data sebesar 6 data. Makna「テメエ」temee secara kontekstual menurut Yonekawa jika dialihbahasakan dalam bahasa Inggris berarti fucker, dipshit, dan asshole (2008:27) yang dalam bahasa Indonesia diartikan berengsek. Penggunaan「人称代 名詞」 ninshoudaimeishi (pronomina persona) kata「テメエ」 temeemengindikasikan makna kata "kau" secara sangat kasar.「テメエ」temee ini sangat tabu untuk diucapkan. Karena itu hanya penutur yang sedang dalam kondisi terhimpit atau tertekan saja yang berani mengucapkannya misalnya dalam kondisi psikologis marah. Menurut pernyataan native speaker, Kengo Nakamura, selaku triangulator data penelitian, tuturan 「テメ 工」 temee seringkali digunakan oleh para pria karena dinilai sangat kasar. Bahkan di Jepang, orangtua akan memarahi anaknya

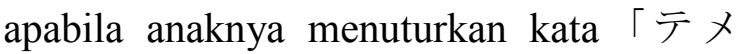
工」 temee di lingkungan rumah.

Kemudian kemunculan terbanyak keempat yakni $「 く そ 」 k u s o$ yang berarti tahi dengan perolehan data sebesar 5 data. Lalu peringkat kelima yaitu「最低」saitei yang bermakna harfiah rendahan dengan perolehan data sebesar 4 data. Lalu peringkat keenam yaitu「地獄」jigoku yang bermakna neraka dan 「Fuck」fuck (fornication under consent of the king) yang bermakna hubungan intim telah mendapatkan ijin dari raja dengan perolehan data yang sama yakni sebesar 3 data. Sementara itu pada peringkat ketujuh tuturan 「豚」 buta yang bermakna babi,

$\lceil$ Shit」 shit yang bermakna tahi,「チン ポ」 chimpo yang bermakna,「やろう」 yarou yang bermakna berengsek, 「マザコ ン」 mazakon yang bermakna mother complex, dan「死ぬ」 shinu yang bermakna mati, sama-sama memiliki perolehan data masing-masing sebesar 2 data.

Sementara itu sisanya pada peringkat kedelapan yakni tuturan「おしつ こ」oshikko yang bermakna pipis, 「欽 玉」 kintama yang bermakna buah pelir, 「キス」kisu yang bermakna cium, 「出 ちゃう」 dechau yang bermakna keluar, 「スッパチェーリ」 suppacheeri yang bermakna perawan/perjaka,「悪魔」akuma yang bermakna setan/jin,「鬼」 oni yang juga bermakna setan, 「餓鬼」gaki yang bermakna roh kelaparan, 「HIV」HIV yang bermakna nama virus menular HIV (Human Immunodeficiency Virus) yaitu virus yang menyerang sel CD4/ sel darah putih dan menjadikannya tempat berkembang biak kemudian merusaknya sehingga tidak dapat digunakan lagi dan sistem kekebalan tubuh manusia yang terjangkit akan hilang,

$\lceil$ AIDS 」AIDS yang bermakna penyakit AIDS (Acquired Immune Deficiency Syndrome) yaitu sekumpulan gejala yang didapatkan dari penurunan kekebalan tubuh akibat kerusakan sistem imun yang disebabkan oleh infeksi HIV, 「 Jesus Christ」Jesus Christ yang bermakna tuhan Yesus Kristus,「畜生」Chikushou yang bermakna hewan ternak,「スルメ」 surume yang bermakna sotong,「チキン」 
chikin yang bermakna pengecut, 「ゴリ ラ」 gorira yang bermakna gorila,「は げ」 hage yang bermakna gundul, 「ボ ケ」 boke yang bermakna bodoh, dan「あ ほ」 aho yang juga bermakna bodoh. Semuanya memiliki perolehan data yang sama, masing-masing sebesar 1 data.

Selanjutnya agar lebih spesifik maka berikut ini akan disajikan beberapa data berdasarkan klasifikasi bentuk tuturan tabu yang dianggap representatif untuk mewakili karakteristik keseluruhan data.

\section{a. Bentuk Tuturan Tabu}

Data dalam film Con, DMC, CZ 1, dan $\mathrm{CZ} 2$ yang menggunakan tuturan tabu dengan bentuk organ tubuh terdapat 3 data. Yang dimaksud dengan organ tubuh yaitu bagian anggota tubuh baik yang ada di luar maupun dalam seperti organ tubuh dalam (jantung, hati, ginjal, lambung, usus, empedu, pankreas, dan lainnya), organ tubuh luar (payudara, dada, penis, testikel, pantat, dan lainnya). Perhatikan contoh (3) berikut.

Konteks : Kintama Garusu menyanyikan lagu tentang penghinaan terhadap DMC yang dianggap menjijikkan.

\section{金玉ガルス：チェリーボイ。昨日のマ マに化粧を教わる。明日 はパパに衣装を狙う。潰 せ潰せ潰せ、金玉を潰せ。} Kintama :Cherryboy. Kinou no mama ni Garusukesho o osowaru. Ashita wa papa ni ishou o nerau. Tsubuse tsubuse tsubuse, kintama o tsubuse.

: "Perjaka. Kemarin kau minta diajarkan oleh mama cara berdandan. Besok kau mengincar baju milik papa. $\mathrm{Ku}$ hancurkan kuhancurkanku hancurkan, buah pelirmu ku hancurkan."

(DMC 42:37-43:04)
Pada tuturan (3) penutur adalah 「金 玉ガルス」 Kintama Garusu yang merupakan grup band metal yang beranggotakan para musisi wanita, sementara itu petutur adalah grup band metal bernama DMC yang beranggotakan para musisi laki-laki. Penutur sangat membenci grup band DMC karena kerapkali menghina hargadiri wanita dengan cara menyamakan wanita dengan babi yang harus diperkosa. Karena itu penutur menyanyikan lagu berisikan tentang penghinaan balasan terhadap petutur. Penutur menyanyikan lagu dengan sinis, penuh semangat dan kebencian sehingga para fansnya yang mayoritas wanita pun manjadi turut bersemangat, mendukung, dan sangat antusias.

Tuturan 「 金玉 玉 kintama berdasarkan teori bentuk tuturan tabu yang telah dikemukakan oleh Allan dan Burridge (2006) termasuk ke dalam bentuk tuturan tabu terkait organ tubuh. Tuturan 「金玉」 kintamasendiri dialihbahasakan oleh Fargo (2007: 77) dalam bahasa Inggris menjadi nads yang dalam bahasa Indonesia memiliki makna harfiah buah zakar. Sementara itu dalam terjemahan Matsura (1994: 498)「金玉」kintama memiliki makna harfiah buah pelir, buah zakar, dan testikel.

Bentuk tuturan tabu yang digunakan oleh penutur pada tuturan (3) adalah kategori hinaan dengan cara menyebutkan organ tubuh, lebih tepatnya yaitu organ kemaluan laki-laki. Tuturan $「$ 金玉」 kintamadiucapkan oleh penutur dengan kondisi psikologis marah dan kesal. Tuturan

$\lceil$ 金玉」 kintama ini biasa digunakan ketika seseorang memang berniat ingin mengucapkan tuturan yang dinggap tabu. Karena ada tuturan lain yang bermakna sama namun lebih ilmiah sehingga mengurangi sifat ketabuan suatu tuturan yaitu kata testicles. 
Tuturan (2) mengindikasikan bahwa penutur sangat marah dan kesal pada petutur sehingga penutur berani menyebut buah pelir yang merupakan organ intim laki-laki. Nyanyian penutur berisikan hinaan pada petutur yang dianggap sebagai anak perjaka yang manja yang selalu berlindung pada orangtuanya. Dengan cara bernyanyi penutur bertujuan agar lagunya terdengar oleh petutur sehingga rasa kekesalannya dapat tergantikan dengan cara menghina dan mengumpati petutur sepuasnya. Penutur berniat untuk mengobarkan bendera peperangan pada petutur agar petutur mengetahui bahwa hargadiri kaum wanita tidak bisa diinjakinjak seenaknya oleh kaum laki-laki.

\section{b. Motif Tuturan Tabu}

Data dalam film Con, DMC, CZ 1, dan $\mathrm{CZ} 2$ yang menggunakan tuturan tabu dengan motif taboo of propriety (tabu karena sesuatu yang dirasa tidak sopan atau tidak pantas) terdapat 52 data. Yang dimaksud dengan motif taboo of propriety yaitu tuturan tabu yang berkaitan dengan seks, bagian-bagian tubuh tertentu dan fungsinya, serta beberapa kata makian yang semuanya tidak pantas atau tidak santun untuk diungkapkan. Misalnya pengungkapan tuturan penis, buang air besar, kotoran, payudara, bercinta, dan buah zakar. Perhatikan contoh (4) berikut.

Konteks : Setelah pertarungan hebat melawan Jack, Krauser menyanyikan lagu baru dengan irama balada yang jauh dari kesan death metal. Bos yang mendengarnya saat itu sangat marah hingga melemparkan puntung rokok ke arah jidat Krauser sambil mengumpat dengan nada keras.

(4)

社長 : Fuck You!!!

Shachou : Fuck You!!!

\section{: "Fuck You!!!"}

(DMC 01:36:38-01:36:56)

Pada tuturan (4) penutur adalah「社 長」 shachou yaitu bos dari grup band DMC. Sementara itu petutur adalah Johannes Krauser II yang merupakan vokalis grup band bernama DMC yang beraliran musik death metal. Petutur dalam film ini memiliki dua karakter yang berlawanan, selain berperan menjadi Krauser, petutur sebenarnya adalah seorang pria melankolis dan kalem yang bernama Souichi Negishi. Bertolak belakang dengan karakter penutur yang memiliki karakter keras, kasar, dan tempramen. Penutur sering memarahi petutur apabila petutur berkarakter lembek dan tidak dapat memenuhi keinginannya.

Bentuk tuturan tabu yang digunakan oleh penutur pada tuturan (4) adalah umpatan mengenai aktivitas seksual. Tuturan $\lceil$ Fuck You」 memiliki makna harfiah dalam bahasa Indonesia yakni ku setubuhi kau. Kata 「Fuck」 berasal dari kepanjangan fornication under consent of the king yang bermakna hubungan intim telah mendapatkan ijin dari raja. Dalam sejarahnya diceritakan bahwa dahulu kala di Negara Inggris, penduduknya tidah boleh melakukan hubungan seksual tanpa ijin dari sang Raja. Saat mereka ingin memiliki anak, mereka harus mengajukan ijin kepada pihak kerajaan. Setelah itu pihak kerajaan akan memberikan "Tanda / Kartu" untuk digantung di pintu pasangan tersebut selama mereka berhubungan. Tanda tersebut bertuliskan "Hubungan intim telah mendapatkan ijin dari raja", atau dalam bahasa mereka ditulis dengan "Fornication Under Consent of The King" (F.U.C.K) (Wikipwdia, 2009).

Tuturan (4) diucapkan oleh penutur dalam konteks emotif marah (Boeree, 2008:124). Penutur pada mulanya sangat bahagia menyaksikan petutur berhasil 
mengalahkan legenda musik death metal, Jack. Namun dengan sekejap penutur merasa sangat marah karena mengetahui petutur menyanyikan lagu berirama balada yang sangat bertolak belakang dengan aliran musik death metal yang diusung oleh grup band DMC. Karena itulah dengan serta merta dan sambil mengumpat dengan tuturan 「Fuck You」 penutur melemparkan puntung rokok usai dihisap oleh penutur ke arah jidat petutur yang masih bernyanyi di hadapan penontonnya. Petutur tidak menyadari apabila penutur sudah sangat marah dan mengumpatinya dengan umpatan terkait dengan aktivitas seksual.

Sudah jelas bahwa motif yang melatarbelakangi penutur mengucapkan tuturan tabu 「Fuck You」 adalah karena emosi kemarahannya yang meledak. Tuturan tabu「Fuck You」 adalah tuturan yang sangat tidak etis karena bernuansa erotis dengan menyebutkan hal terkait dengan aktivitas seksual. Dengan mengucapkan tuturan tabu「Fuck You」 penutur merasa memiliki kedudukan lebih tinggi dibanding dengan petutur yang hanya merupakan anak buahnya saja. Karena petutur menyanyikan lagu balada yang manja maka penutur merasa bahwa petutur bersikap seperti wanita lemah yang layak untuk disetubuhi. Tuturan tabu $「$ Fuck You $\lrcorner$ ini pada dasarnya digunakan oleh seseorang untuk merendahkan hargadiri orang lain.

\section{c. Fungsi Tuturan Tabu}

Data dalam film Con, DMC, CZ 1, dan CZ 2 yang menggunakan tuturan tabu dengan fungsi direktif terdapat 7 data. Yang dimaksud dengan fungsi direktif adalah fungsi ilokusi yang disebabkan karena penutur ingin tuturan tabu yang disampaikannya menghasilkan suatu efek berupa tindakan yang dilakukan oleh petutur ilokusi, misalnya: memesan, memerintah, memohon, menuntut, dan memberi nasehat. Fungsi tindak tutur direktif ini pun berkaitan dengan tuturan tabu ketika penutur menyuruh petutur untuk melakukan sesuatu dengan cara menghina atau mengumpat. Perhatikan contoh (5) berikut.

Konteks : Serizawa kabur dari kejaran Kepala Polisi karena dia tidak memiliki SIM (Surat Ijin Mengemudi) dan mengebut di jalan. Tuturan ini diucapkan oleh Kepala Polisi sambil mengejar Serizawa.

(5)

$$
\begin{gathered}
\text { 警察の頭:芹沢、チキン! 芹沢、チキ } \\
\text { ン! } \\
\text { : Serizawa, chikin! Serizawa, } \\
\text { chikin! } \\
\text { : Serizawa, ayam! Serizawa, } \\
\text { ayam! }
\end{gathered}
$$

(CZ 1 09:29-09:40)

Pada tuturan (5) penutur adalah「警 察の頭」Keisatsu no atama yaitu Kepala Polisi. Petutur adalah「芹沢」Serizawa yaitu siswa SMA Suzuran. Petutur dikejar oleh penutur atas dasar mengebut di jalan, mengendarai motor tanpa memiliki SIM (Surat Ijin Mengemudi), serta membuat keonaran di jalan. Penutur mengejar petutur dengan mengendarai mobil. Sementara itu petutur terus saja mengebut walau sudah diperingatkan oleh penutur. Petutur bahkan menabrak semua benda dan manusia yang berlalu lalang di hadapannya. Penutur sangat kesal dan menjebak petutur sampai di gang kecil. Agar dapat menarik perhatian petutur maka penutur mencoba menghina penutur dengan mengucapkan tuturan (5) pada petutur yakni tuturan tabu「チキ ン」 chikin yang berarti ayam.

Tuturan tabu yang digunakan oleh penutur pada tuturan (5) adalah bentuk hinaan dengan cara membandingkan seseorang dengan hewan. Melalui tuturan tabu「チキン」 chikin yang bermakna 
ayam, penutur mengekspresikan konteks emotif marah (Boeree, 2008:124). Tuturan inisendiri berasal dari kata serapan bahasa Inggris 'Chicken' yang biasa diucapkan kepada petutur yang memiliki sifat penakut, licik, dan pengecut. Tuturan tabu「チキ ン」 chikin yang diucapkan bermaksud untuk menghina petutur akibat sifat pengecut petutur yang tidak taat hukum karena berusaha lari dari kejaran petutur yang notabene Kepala Polisi. Tuturan ini biasa digunakan untuk menyebut seseorang yang tidak mau menghadapi keadaan dan bersifat pengecut atau tidak jantan. Penutur bermaksud menghina petutur yang takut dengan kejaran polisi dan pengecut dalam menghadapi masalah seperti sifat ayam yang lari ketakutan apabila dikejar.

Tindak tutur yang diungkapkan oleh penutur tersebut memiliki fungsi direktif seperti yang diungkapkan oleh Searle (dalam Leech, 1993:164) yakni memiliki tujuan memerintah petutur. Penutur menghina dengan mengucapkan tuturan tabu「チキン」 chikin agar petutur terpancing emosinya dan tidak lari dari kejaran penutur, sehingga dalam hal ini penutur memerintah petutur untuk menyerahkan diri secepatnya dan menghadapi penutur secara jantan.

\section{e. Strategi X-Femisme Tuturan Tabu}

Data dalam film Con, DMC, CZ 1, dan CZ 2 yang menggunakan tuturan tabu dengan strategi $\mathrm{x}$-femisme tipe eufemisme terdapat 3 data. Yang dimaksud dengan eufemisme adalah suatu strategi komunikasi yang digunakan oleh penutur untuk menghindari pengancaman terhadap wajah 'face'petutur sebagai strategi kesopanan. Eufemisme ini didefinisikan oleh Wardhaugh(2006: 240)sebagai 'ekspresi yang memungkinkan untuk berbicara tentang hal yang tidak menyenangkan'. Eufemisme digunakan sebagai tindakan penyelamatan nama baik seseorang dalam masyarakat. Berikut ini contoh tuturan yang memuat eufemisme tentang aktivitas seksual. Perhatikan contoh (6) berikut.

Konteks : Untuk menarik simpati Makise maka Genji, Ken, dan Chuta mengajak Makise untuk berkencan buta dengan tiga gadis muda. Namun Makise tidak dapat menahan nafsu birahinya.

(6)

$$
\begin{aligned}
\text { 源氏 } & : \text { 源氏です。 } \\
& : \text { Genji desu. } \\
& : \text { “Aku Genji” } \\
\text { ケン } & \text { : そしてこいつは。 } \\
& \text { : Soshite koitsu wa. } \\
& \text { :"dan yang ini adalah” } \\
\text { 牧瀬 } & \text { : 僕マッキです。 }
\end{aligned}
$$

: Boku Makki desu.

: "Aku Makki."

京子：何か油性ペンみたいの名前 だね。

: Nanka yuseipen mitai no namae dane.

: "Kenapa namamu seperti nama spidol permanen?”

牧瀬 : ウー、良い声だな。

: Uh, ii koe dana.

: "Uhh, suara yang cantik."

源氏 : 牧瀬、落ち着け！

: Makise! Ochitsuke!

: "Makise! Tenang!"

牧瀬: だよな。俺何もしない出ちゃ いそうだよ。

: Dayona. Ore nani mo shinai dechai souda yo.

: "Iya, Aku biasa keluar tanpa melakukan suatu apapun."

京子：出ちゃうって何が。

: Dechau tte nani ga?

: "Apa itu keluar?"

牧瀬 : 何がって君男の口からそんな 事をわせるつもりかい。 : Nani ga tte kimi otoko no kuchi 
kara sonna koto o waseru tsumori kai.

: "Apakah kamu hendak memaksa seorang pria untuk menjelaskannya?"

(CZ 1 39:15-40:23)

Pada tuturan (6) penutur adalah 「牧瀬」Makise dan petutur adalah「京 子」Kyoko. Penutur adalah siswa kelas 3 SMA Suzuran. Petutur adalah siswi SMA yang merupakan teman dari teman petutur. Penutur dan petutur belum saling mengenal dan dipertemukan dalam acara blind date (kencan buta) yang diadakan oleh Ken, Genji, dan Chuta. Pada pertemuan pertama penutur sudah merasa tertarik pada petutur. Penutur adalah orang yang mudah terangsang secara seksual, nafsu birahinya sangat tinggi. Karena itu penutur menjadi tegang dan tiba-tiba saja ereksi ketika melihat paras cantik petutur dan mendengarkan suara merdunya ketika berkenalan. Genji menasehati penutur agar dapat rileks karena tingkahnya membuat petutur menjadi risih dan takut. Tapi penutur malah terang-terangan mengatakan bahwa penutur sedang mengalami ejakulasi kepada petutur.

Ditinjau dari segi bentuk tuturan tabu, tuturan 「出ちゃい」dechai berdasarkan teori bentuk tuturan tabu yang telah dikemukakan oleh Allan dan Burridge (2006) termasuk dalam bentuk tuturan tabu terkait dengan aktivitas seksual. Tuturan ini sendiri memiliki makna harfiah dalam bahasa Indonesia yakni mengeluarkan. Maksud dari tuturan ini secara makna gramatikal yaitu mengeluarkan (sperma) atau dalam istilah ilmiahnya disebut sebagai ejakulasi. Mengeluarkan sperma merupakan salah satu aktivitas seksual yang dianggap tabu untuk diucapkan secara lantang di depan umum terutama di depan seorang wanita yang baru dikenal. Karena itu penutur dianggap menuturkan suatu hal yang tabu.

Ditinjau dari segi motif tuturan tabu, tuturan tabu「出ちゃい」dechai termasuk dalam kategori tuturan tabu dengan motif taboo of propriety yakni dianggap tabu karena tuturan tersebut tidak santun dan tidak pantas. Menurut pernyataan native speaker, Emiko Watanabe, selaku triangulator data penelitian, tuturan「出ち やい」 dechai dalam bahasa Jepang bermakna tidak begitu kasar untuk menyatakan mengeluarkan sperma. Tuturan

「出ちゃい」 dechaimenurut Watanabe digunakan oleh masyarakat untuk menyatakan mengeluarkan sperma agar terkesan lebih sopan. Watanabe menyatakan bila seseorang ingin menyatakan suatu kata ejakulasi dengan tujuan agar pertuturannya terkesan lebih standar dan ilmiah maka disarankan menggunakan kata ejaculation. Sementara itu jika seseorang ingin terkesan sangan kasar dan tidak sopan maka tuturan yang sering digunakan dalam bahasa Jepang adalah「イク」iku yang arti harfiahnya adalah pergi, namun makna kontekstualnya adalah sperma yang akan pergi keluar menuju indung telur yakni sama artinya dengan ejakulasi.

Ditinjau dari fungsi tuturan tabu, fungsi tindak tutur penutur pada tuturan 「出ちゃい」dechai adalah fungsi asertif. Tuturan tersebut diucapkan oleh penutur dalam keadaan tegang. Tuturan ini cukup sopan diucapkan walaupun petutur tidak paham dengan maksud tuturan penutur. Karena penutur tidak begitu jelas mengucapkan apa yang sedang dikeluarkannya. Penutur hanya mengutarakan tuturan dengan cara implisit. Penutur mengucapkan tuturan tersebut karena sudah tidak dapat lagi menahan nafsu birahinya dengan ejakulasi.

Ditinjau dari segi konteks emotif tuturan tabu, tuturan「出ちゃい」 
dechaidiucapkan oleh penutur dengan kondisi psikologis ingin. Tuturan ini digunakan untuk menyalurkan keinginannya untuk mengeluarkan sperma karena melihat kecantikan wanita yang diperkenalkan padanya. Tuturan ini dainggap tabu karena tidak etis menyatakan hal itu di depan wanita.

Dari keempat tinjauan di atas yakni dari segi bentuk, motif, fungsi, dan konteks emotif tuturan tabu, maka dapat ditarik suatu kesimpulan bahwa strategi $\mathrm{x}$-femisme yang digunakan oleh penutur adalah tipe eufemisme. Karena tuturan tabu「出ちゃ い」 dechai dinilai halus dan implisit. Watanabe, selaku native speaker sekaligus triangulator penelitian menambahkan bahwa tuturan「出ちゃい」dechai ini memang tabu maknanya, namun masih terkesan sopan dan tersembunyi untuk digunakan dibandingkan dengan tuturan lain seperti ejaculation dan「イク」 $i k u$ yang jauh dari kesan sopan.

\section{Penutup}

Berdasarkan dari pembahasan sebelumnya maka dapat ditarik simpulan sebagai hal berikut.

1. Bentuk penggunaan tuturan tabu berdasarkan teori Allan dan Burridge (2006) dengan sistem ekskresi (excretory system) yaitu 1 data, organ tubuh (organs) yaitu 3 data, aktivitas seksual (sexual activities) yaitu 5 data, kelainan seksual (sexual disorders) yaitu 2 data, kematian (death) yaitu 2 data, pembunuhan (kill) yaitu 7 data, penamaan/ pengalamatan (naming, addressing) yaitu 13 data, tempat/ objek sakral/ religi (sacred things, God, religion) yaitu 7 data, penyakit (disease) yaitu 2 data, hewan (animal) yaitu 6 data, fisik tidak ideal (not ideal physical) yaitu 1 data, mental di bawah normal (abnormal mental, stupid) yaitu 14 data, dan kotoran (dirt) yaitu 7 data.
2. Motif penggunaan tuturan tabu berdasarkan teori Ullmann (2006) dengan motif tabu karena sesuatu yang menakutkan (taboo of fear) yaitu 7 data, motif tabu karena membuat perasaan tidak enak (taboo of delicacy) yaitu 11 data, dan motif tabu karena sesuatu yang tidak santun dan tidak pantas (taboo of propriety)yaitu 52 data.

3. Fungsi penggunaan tuturan tabu berdasarkan teori Searle (dalam Leech, 1993) dengan fungsi asertif yaitu 16 data, fungsi direktif yaitu 7 data, fungsi komisif yaitu 1 data, fungsi ekspresif yaitu 46 data, dan fungsi deklaratif nol data.

4. Konteks emotif penggunaan tuturan tabu berdasarklan teori Boeree (2006) dengan konteks keterkejutan yaitu 3 data, konteks ketakutan yaitu 4 data, konteks kemarahan yaitu 39 data, konteks kesedihan yaitu 7 data, konteks keinginan yaitu 7 data, konteks kebahagiaan yaitu 7 data, dan konteks kebosanan yaitu 3 data.

5. Strategi $\mathrm{x}$-femisme penggunaan tuturan tabu berdasarkan teori Allan dan Burridge (2006) dengan tipe disfemisme yaitu 27 data, ortofemisme yaitu 40 data, dan eufemisme yaitu 3 data.

Dari hasil penelitian dapat disimpulkan secara umum bahwa penggunaan tuturan tabu senantiasa didasari dengan latar belakang aspek kebahasaan seperti bentuk, motif, fungsi, konteks emotif, dan strategi $\mathrm{x}$-femisme. Kemudian, penggunaan tuturan tabu juga mempengaruhi keberhasilan komunikasi yang diharapkan antara penutur dan petutur.

\section{Daftar Pustaka}

Allan, Keith dan Burridge, Kate. 2006. Forbidden Words-Taboo and the Censoring of Language. Cambridge: Cambridge University Press. 
Asyuri, Sandi. 2009. Awal dan Arti Kata F.U.C.K. (http://wikipediadunia.blogspot.com/2009/08/awaldan-arti-kata-fuck.html, akses terakhir tanggal 13 Juli 2013, pukul 22.45 WIB)

Boeree. C. George. 2008. General Psychology.

Prismasophie.

Djajasudarma, T. Fatimah. 1993. Metode Linguistik: Ancangan Metode Penelitian dan Kajian. Bandung: Eresco.

Fargo, Matt. 2007. Dirty Japanese: Everyday Slang from "What's Up" to "F*\%\# Off!". Berkeley: Ulysses Press.

Freud, Sigmund. 1918. Totem and Taboo. New York: Vintage Books.

Hashiuchi, Takeshi. 1999. ディスコース： 談話の織り成す世界 (DeisukousuDanwa no Orinasu Sekai). Tokyo: Kuroshio.

Hughes, Geoffrey. 1991. Swearing: A Social History of Foul Language, Oaths, and Profanity in English. Massachusetts: Oxford UK \& Cambridge USA.
International Internship Programs. 2001. Kodansha International. Tokyo: Kodansha International Ltd.

Leech, Geoffrey. 1993. Prinsip-prinsip Pragmatik. Diterjemahkan oleh M.D.D. Oka dan Setyadi Setyapranata. Jakarta: Universitas Indonesia Press.

Moleong, Lexy J. 2005. Metodologi Penelitian Kualitatif Edisi Revisi. Bandung. Remaja Rosdakarya.

Sugiyono. 2008. Memahami Penelitian Kualitatif. Bandung: Alfabeta.

Ullmann, Stephen. 2009. Pengantar Semantik. Diadaptaasi oleh Sumarsono. Yogyakarta: Pustaka Pelajar.

Wardhaugh, Ronald. 2006. An Introduction to Sociolinguistics $5^{\text {th }}$ Edition. Malden: Blackwell Publishing.

Yonekawa, Akihiko. 2008. Beyond Polite Japanese. Tokyo: Kodansha.

Yule, George. 1997. Pragmatics. Oxford: Oxford University Press.

Jakobson, Roman. 1998. The Speech Event and the Functions of Language. Oxford: Oxford University Press.

Jakobson, Roman. 1998. The Speech Event and the Functions of Language. Oxford: Oxford University Press. 